\title{
Database of German North Sea Salt Marshes - changes in vegetation and elevation
}

\author{
Sigrid Suchrow, Nina Pohlmann, Martin Stock \& Kai Jensen
}

\begin{abstract}
The Database of German North Sea Salt Marshes (GIVD ID EU-DE-029) comprises 423 1m²-plots from German North Sea salt marshes, tracing back to the project "Thematic Mapping and Sensitivity Study of Mudflat Areas in the German Wadden Sea". In 1987-1991 and again in 2007, plots along 31 transects - covering the mainland coast of Schleswig-Holstein - were investigated for their vascular plant species composition (species' presence and cover using Londo scale) as well as structural and spatial variables like grazing management, position and elevation in relation to mean high tide. Frequent vegetation-types were Spartinetum anglicae, Puccinellietum maritimae and Festucetum rubrae. This consistent data set allowed and still aims to determine spatial and geographical differences regarding changes in species diversity, dominance structure and functional traits in relation to driving environmental variables, and, especially, to study changes in elevation (due to accretion and subsidence) and vegetation in the salt marshes with regard to future sea level rise. Further, our data provide a baseline for future studies of possible changes in biodiversity, vegetation composition and species distribution pattern caused e.g. by invasive plant species, conservation management or sea level rise, which may in turn further improve future salt marsh management.
\end{abstract}

Keywords: biodiversity; conservation; management; sea level rise; sedimentation; Wadden Sea.

GIVD Database ID: EU-DE-029

Last update: $2012-07-15$

\section{Database of German North Sea Salt Marshes - Changes in Vegetation and Elevation}

Scope: The data set comprises $4231 \mathrm{~m}^{2}$-plots from salt marshes at the German mainland North Sea coast. In 1987-1991 and again 2007, the plots were investigated (along 31 transects) for their species composition, their elevation in relation to mean high tide and other structural parameters. Our data provide a baseline for future studies of possible changes in biodiversity, vegetation composition and species distribution pattern caused e.g. by conservation management or sea level rise.

Status: completed and continuing

Period: 1987-2007

Database manager(s): Sigrid Suchrow (ssuchrow@web.de, sigrid.suchrow@botanik.uni-hamburg.de); Martin Stock (martin.stock@lkn.landsh.de); Kai Jensen (kai.jensen@botanik.uni-hamburg.de)

Owner: at present: Sigrid Suchrow and Nina Pohlmann

later on: Martin Stock for the Schleswig-Holstein Agency for Coastal Defence, National Park and Marine Conservation - National Park Authority Web address: [NA]

Availability: after blocking period

Database format(s): Excel

Online upload: no Online search: no

Publication: Bernem, K.H. van, M. Grotjahn, J. Knüpling, A. Müller, L. Neugebohrn, G. Ramm, G. Sach \& S. Suchrow (1992): Thematic Mapping and Sensitivity Study of Mudflat Areas in the German Wadden Sea. In: Dankers, M., C.J. Smit \& M. Scholl [Eds.]: Proceedings of the 7th

International Wadden Sea Symposium. Ameland, the Netherlands, 22-26 October 1990. Publication Series Netherlands Institute for Sea Research No. 20, 237-238, 1992

Plot type(s): normal plots; time series

Non-overlapping plots: 423

Plot-size range: $1-1 \mathrm{~m}^{2}$

Total plot observations: 423

Estimate of existing plots: 423

Completeness: $100 \%$

Countries: DE: $100.0 \%$

Forest: $0 \%$ - Non-forest: aquatic: $0 \%$; semi-aquatic: $100 \%$; arctic-alpine: $0 \%$; natural: $0 \%$; semi-natural: $0 \%$; anthropogenic: $0 \%$

Guilds: all vascular plants: $100 \%$

Environmental data: altitude: $100 \%$; microrelief: $100 \%$; other soil attributes: $100 \%$

Performance measure(s): cover: $100 \%$

Geographic localisation: GPS coordinates (precision $25 \mathrm{~m}$ or less): $100 \%$

Sampling periods: $1980-1989: 50.0 \% ; 2000-2009: 50.0 \%$

Information as of 2012-07-25; further details and future updates available from http://www.givd.info/ID/EU-DE-029

Sigrid Suchrow* (ssuchrow@ web.de, sigrid.suchrow@botanik.uni-hamburg.de), Nina Pohlmann (ninapiratna@gmx.de), Kai Jensen (kai.jensen@botanik.uni-hamburg.de)

Biocenter Klein Flottbek and Botanical Garden, University of Hamburg, Ohnhorststr. 18, 22609 Hamburg, GERMANY 
Martin Stock (martin.stock@1kn.landsh.de)

Schleswig-Holstein Agency for Coastal Defence, National Park and Marine Conservation - National Park Authority, Schlossgarten 1, 25832 Tönning, GERMANY

*Corresponding author 